To cite this document: Sabina Scarpellini, Raquel Ortega-Lapiedra, Miguel Marco-Fondevila, Alfonso ArandaUsón, (2017). "Human capital in the eco-innovative firms: a case study of eco-innovation projects", International. Journal of Entrepreneurial Behavior \& Research, Vol. 23 Issue: 6, pp.919-933, https://doi.org/10.1108/ IJEBR-07-2017-0219 Permanent link to this document: https://doi.org/10.1108//JEBR-07-2017-0219

\title{
Human capital in the eco-innovative firms: a case study of eco-innovation projects
}

\author{
Sabina Scarpellini \\ University of Zaragoza - Department of Accounting and Finance. CIRCE Institute \\ (Spain) \\ Raquel Ortega-Lapiedra \\ University of Zaragoza. Department of Management (Spain) \\ Miguel Marco-Fondevila \\ CIRCE Institute (Spain) - University of Zaragoza. Department of Management \\ Alfonso Aranda-Usón \\ University of Zaragoza. Department of Management (Spain)
}

\section{Introduction}

It is generally accepted that business competitiveness in the long term goes through a compromise between productivity and resources consumption which maximizes efficiency "doing more with less". Herein lays the special interest that eco-innovation represents for the environmental sustainability in business. In this context, we cannot forget the role of Human Capital in the interrelated processes for eco-innovation. HC is generally considered an essential part of innovation (OECD, 2011). Yet, the characteristics of the human capital involved in this process have to be analyzed and optimized

The HR innovativeness capabilities, defined by Hurt et al (1977) as their willingness to change, represent the intangible element of interest in innovating, which can be considered more likely than tangible resources to produce a competitive advantage, as Hitt el al (2001) suggested for innovation. Within the current analysis, corporate entrepreneur is referred to the stock of human capital involved at the level of the firm, and is characterized by its search for new alternatives or ways to develop the business, taking into account the nuances of the various representative authors from Susbauer (1973) to Parker (2011). The knowledge-based theory of the firm emphasizes also the central role of the individual in the creation and as the source of knowledge (Antoncic 
To cite this document: Sabina Scarpellini, Raquel Ortega-Lapiedra, Miguel Marco-Fondevila, Alfonso ArandaUsón, (2017). "Human capital in the eco-innovative firms: a case study of eco-innovation projects", International. Journal of Entrepreneurial Behavior \& Research, Vol. 23 Issue: 6, pp.919-933, https://doi.org/10.1108/ IJEBR-07-2017-0219 Permanent link to this document: https://doi.org/10.1108//JEBR-07-2017-0219

and Hisrich, 2001; Grant 1996; Nicolopoulou, 2014). Thus, individuals are too the main actors in innovation. Individual brings to the firm in the form of knowhow, creativity and the ability to identify and exploit opportunities and ideas for innovation.

This strategic behavior gives the organization towards opening new horizons and the discovery of new businesses within the same entity, which allows existing organizations develop and diversify into other activities or business areas (Burgelman, 1983). At any rate, corporate entrepreneurship allows an incumbent firm to make full utilization of its resources and capture new opportunities (Morris and Kuratko, 2002). Therefore, innovation and venturing are considered as two dimensions of corporate entrepreneurship (Covin and Miles, 1999; Guth and Ginsberg, 1990; Yiu and Lau 2008) and the role of the human capital involved in the innovation processes has to be considered as a resource that could foster the identification and/or exploitation of innovative ideas by corporate entrepreneurs (Coduras et. al., 2011, Birkinshaw, 1997). Hong Chung and Gibbons (1997), state that the entrepreneurial behavior within an organization can only be effectively created and controlled through an appropriate corporate culture. Both, entrepreneurs and innovators introduce new inventions into productive activities (Wu and Huarng, 2015).

Dess et al (2003), and later Kuratko (2007) propose a comprehensive model from the point of view of management and transfer of knowledge which combines three fundamental aspects, such as environmental factors, those on your own organization, and the consequences associated with corporate entrepreneurship. Finkle (2012) pointed out that innovation is a key ingredient of corporate entrepreneurship where one can take an idea or invention and create something new of value (Phan, 2009). The innovation challenge is essentially around processes of search (for innovation trigger signals), selection (resource allocation) and implementation. As many writers have noted, 
To cite this document: Sabina Scarpellini, Raquel Ortega-Lapiedra, Miguel Marco-Fondevila, Alfonso ArandaUsón, (2017). "Human capital in the eco-innovative firms: a case study of eco-innovation projects", International. Journal of Entrepreneurial Behavior \& Research, Vol. 23 Issue: 6, pp.919-933, https://doi.org/10.1108/ IJEBR-07-2017-0219 Permanent link to this document: https://doi.org/10.1108//JEBR-07-2017-0219

organizations develop 'routines’ for these activities, and these behavior patterns gradually become embedded and reinforced into policies, structures and processes (Arrow, 1962; Hill and Rothaermel, 2003; Jimenez-Jimenez and Sanz-Valle, 2011; Nelson and Winter, 1982).

Human capital has emerged in the literature as an antecedent of innovation that helps to create value (Huarng and Yu, 2011; Ribeiro and Huarng, 2013). As Rossi et al (2015) pointed out, managing existing resources, as opposed to finding new resources, is a fundamental principle that emphasizes the importance of resources characterized by a knowledge nature (Barney et al, 2011).

In this framework, the relationship between HR and innovation is mainly focused to the human capital its measure (Fitjar et al., 2011; Ganotakis, 2012; Gimmon and Levie, 2010; Robson et al., 2012), the culture of innovation (Rule and Irwin, 1988) or the workforce's level of education (McGuirk and Jordan 2012). Creativity (Storper and Scott 2008), work experience and occupation (Albers and Brewer, 2003; Ganotakis, 2012; Schneider et al 2010) have been analyzed as well.

Pizarro-Moreno et al (2011) shows that human capital that is the set of knowledge, skills and abilities they have and workers use (Schultz, 1961), positively influences innovation. Kelley et al (2009) explained how the process of innovation-based corporate entrepreneurship requires a search for diverse sources of knowledge, both existing and new, and they also reveal implications for the selection of project leaders and the design entrepreneurship programs for innovation. This brings us to Porter (1990) who contends that competitive advantage can only be achieved through innovation and it needs the human capital.

In general terms, there is an abundant literature about the HC related to the innovation process but the empirical studies so far do not reach uniform measurement results given 
To cite this document: Sabina Scarpellini, Raquel Ortega-Lapiedra, Miguel Marco-Fondevila, Alfonso ArandaUsón, (2017). "Human capital in the eco-innovative firms: a case study of eco-innovation projects", International. Journal of Entrepreneurial Behavior \& Research, Vol. 23 Issue: 6, pp.919-933, https://doi.org/10.1108/ IJEBR-07-2017-0219 Permanent link to this document: https://doi.org/10.1108//JEBR-07-2017-0219

the intangible measured resource for the specific eco-innovation initiatives where the innovation pursues the environmental improvement as well. Porter and van der Linde (1995) were among the first to suggest that cost reductions can be achieved by proactive environmental initiatives (Berrone et al, 2013), but sustainability innovation has increased its presence in the literature (Brunnermeier, 2003; Cohen, 2006; Foxon and Pearson, 2008; Hansen et al, 2009; Martin, McNeill, and Warren-Smith, 2013; Rennings, 2000;), thus the “ecopreneurship” (Bennet, 1991) has to be considered part of the innovation process (Pastakia, 1998).

In the complex process of eco-innovation, where innovation and environmental knowledge is mixed, it has to be taken into account that innovation 'greenness' is a relative concept (Antonioli et al, 2013; Scott and Thompson, 2012; Zhu et at, 2009), constantly defined and redefined by the firm making and offering the product, end-users of the product/process, the competitors and regulators in the market or other individuals or organizations who claim to be stakeholders in the 'green' value chain.

In the literature there are different definitions of eco-innovation (Andersen, 2002; Carrillo-Hermosilla et al, 2010; Horbach et al, 2012; Kemp and Pearson, 2007; OECD, 2009; Scarpellini et al, 2012), using the term innovation in a broad sense, as defined by the Oslo Manual (OECD, 2005). In general terms, eco-innovation takes place around the new techno-economic conditions but is essentially about replacing existing products, processes and services with variants which are more aligned to a 'do better' approach in sustainable terms (Seebode et al., 2012) and a number of multiple topics are related to it in firms (Holt 2012). Nevertheless, improved knowledge flow (Van der Borgh, 2012) and the integration of environmental values into the organizational inertia is still found to be a major obstacle to knowledge sharing (Sing Wong, 2013; Zhou and Li, 2012). 
To cite this document: Sabina Scarpellini, Raquel Ortega-Lapiedra, Miguel Marco-Fondevila, Alfonso ArandaUsón, (2017). "Human capital in the eco-innovative firms: a case study of eco-innovation projects", International. Journal of Entrepreneurial Behavior \& Research, Vol. 23 Issue: 6, pp.919-933, https://doi.org/10.1108/ IJEBR-07-2017-0219 Permanent link to this document: https://doi.org/10.1108//JEBR-07-2017-0219

Corporate Social Responsibility (CSR) and environmental innovation has also been related (Siltaoja, 2014), but sustainable entrepreneurship has been distinguished (Schaltegger, 2002) as a form of corporate environmental and social responsibility activities that allows management to assess its state of environmental and economic activities in relation to others. In summary, the core motivation and main goals identified with eco-entrepreneurship are to earn money through contributing to solving environmental problems (Delgado-Verde et al, 2015; Lober, 1998; Schaltegger and Wagner, 2010; Von Krogh and Geilinger, 2014).

In this scenario, it should be noted that over the last decades, management scholars have increasingly examined environmental issues and their research has provided us with an opportunity to integrate different approaches (Marshall et al, 2005). From existing theoretical and empirical research, there is increasing evidence that managers within a firm have a significant impact on the degree to which a firm pursues environmental initiatives (Kirkwood and Walton (2010); Marshall et al, 2005; Prakash, 2001; Sharma, 2000).

In this study, by definition, firms are proactive in eco-innovation when they pursue a proactive innovation strategy focused on eco-efficiency results and they are considered pro-active from the environmental point of view as well taking into account those capabilities for sustainability and innovation (Marchi et al, 2012; Mercier-Laurent, 2011;) such as that of being able to integrate stakeholders in such firms (Aragon-Correa and Sharma, 2003).

As a result of the literature review, it can be observed that although common sense suggests human capital is one of the keys to developing any innovation, whether radical or incremental, very little empirical evidence has focused on this resource, probably because of the their joint measurement difficulty. It is true that many years of 
To cite this document: Sabina Scarpellini, Raquel Ortega-Lapiedra, Miguel Marco-Fondevila, Alfonso ArandaUsón, (2017). "Human capital in the eco-innovative firms: a case study of eco-innovation projects", International. Journal of Entrepreneurial Behavior \& Research, Vol. 23 Issue: 6, pp.919-933, https://doi.org/10.1108/ IJEBR-07-2017-0219 Permanent link to this document: https://doi.org/10.1108//JEBR-07-2017-0219

quantitative analysis help to answer the question "which are the determinants for ecoinnovation?”, but this is only and external target that comes from social, cultural, political and economic context. Nowadays it should be consider one step forward and to stress the social values and the individual attributes towards corporate entrepreneurship in the eco-innovative organizations to obtain new positions and new added value.

Given these premises, this study sets the following question "what is the impact of the human capital in pro-active companies in terms of eco-innovation”? That means identifying some eco-innovative companies and trying to understand if knowledge related variables have any influence in these eco-innovative results as a corporate entrepreneurship variable.

To this purpose, the study was focused on analysing some heavily polluting industries that are experiencing the environmental pressures in their decision-making and in their operations (Aragon-Correa, 1988; Florida and Davison, 2001; Hoffman, 1999; Ramus and Steger, 2000; Sharma et al, 1999; Sharma, 2000). Consequently, the general purpose of this qualitative research study is to explain the influence of human capital (HC) in the organizations in terms of eco-innovative entrepreneurship and the existing relations of these resources with other economic and finance resources, and capabilities of the firms. A secondary challenge of the research is to define and measure the available human capital in firms for those eco-innovative processes.

From this theoretical background, first, the research sets out questions that kicked off from the introductory theoretical background with a qualitative analysis of eight applied eco-innovation cases studies that are described in the following section of the paper. Second, the study summarizes the research design and then presents the main findings in terms of the patterns observed and the measurement of the available human capital 
To cite this document: Sabina Scarpellini, Raquel Ortega-Lapiedra, Miguel Marco-Fondevila, Alfonso ArandaUsón, (2017). "Human capital in the eco-innovative firms: a case study of eco-innovation projects", International. Journal of Entrepreneurial Behavior \& Research, Vol. 23 Issue: 6, pp.919-933, https://doi.org/10.1108/ IJEBR-07-2017-0219 Permanent link to this document: https://doi.org/10.1108/IJEBR-07-2017-0219

for eco-innovation. Finally, the principal results are discussed, presenting the achieved conclusions.

\section{Research Design}

This study uses data reached through an intensive campaign ${ }^{1}$ launched within a collaborative public/private framework to promote the eco-innovation among companies, including SMEs (Llera et al, 2013). In the framework of the campaign, more than 50 eco-innovative projects were disseminated and analyzed (Scarpellini et al, 2016). Among those projects, eight study cases were selected to specifically analyze the human capital for eco-innovation thanks to the availability of data and the pro-activity of firms to collaborate with the study (Table 1). The time frame of the field work was the year 2014.

Table 1.- List of selected companies (alphabetical order) ${ }^{2}$

\begin{tabular}{lll} 
Company & Website & $\begin{array}{l}\text { Eco-innovation project disseminated during the } \\
\text { campaign }\end{array}$ \\
\hline $\begin{array}{l}\text { BSH ELECTRODOMESTICOS ESPAÑA } \\
\text { SA }\end{array}$ & www.bsh-group.es/ & $\begin{array}{l}\text { Eco-design of screws for appliances } \\
\text { manufacturing }\end{array}$ \\
\hline $\begin{array}{l}\text { CONSTRUCCIONES Y AUXILIAR DE } \\
\text { FERROCARRILES, SA }\end{array}$ & www.caf.net & $\begin{array}{l}\text { Environmental Communication in rail vehicles } \\
\text { manufacturing }\end{array}$ \\
\hline GENERAL MOTORS ESPAÑA SLU & www.opel.es & Efficient Vehicles Painting System \\
\hline LACASA SA & www.lacasa.es & Sustainability in a candy manufacturing plant \\
\hline MAC PUAR SA & www.macpuarsa.es & Eco-design of Lifts \\
\hline MONDO TUFTING SA & www.mondoiberica.com & Eco-design of artificial turf for sports fields \\
\hline PHILIPS IBERICA SAU & www.philips.es & Efficient regulation of lighting Systems \\
\hline TAIM WESER SA & www.taimweser.com & Eco-design of a biomass gasifier \\
\hline
\end{tabular}

The selected companies were required to submit detailed "Project's sheets" specifying the key characteristics of the chosen eco-innovation projects regarding investment, details of implementation, timing, location, type and objectives of eco-innovation, carbon emissions, resources used, waste saved, process description, products or services to which

\footnotetext{
${ }^{1}$ The Campaign was financed by the Regional Government of Aragón (Spain) and the Spanish Ministry of Economy and Competitiveness. More information about the campaign at: http://ecoinnovacion.fcirce.es/campa\%C3\%B1-para-el-fomento-de-laeco-innovaci\%C3\%B3n-empresarial-en-arag\%C3\%B3n (Accessed September 2015).

2 The data can be offered in an aggregate analysis due to the confidential rules of the Campaign, The Companies have been listed in an alphabetical order and it does not correspond to the numerical code assigned to each firm.
} 
To cite this document: Sabina Scarpellini, Raquel Ortega-Lapiedra, Miguel Marco-Fondevila, Alfonso ArandaUsón, (2017). "Human capital in the eco-innovative firms: a case study of eco-innovation projects", International. Journal of Entrepreneurial Behavior \& Research, Vol. 23 Issue: 6, pp.919-933, https://doi.org/10.1108/ IJEBR-07-2017-0219 Permanent link to this document: https://doi.org/10.1108//JEBR-07-2017-0219

it was applied and the position within the value chain. The close collaboration with the firms permitted the access to all required information so as to analyze different variables in applied case studies.

The economic and financial variables were extracted from SABI’s database ${ }^{3}$, while the Human Resources information within the companies, as well as other important data such as certification or the existence of internal initiatives to promote eco-innovation, were gathered through a specific questionnaire addressed to the participating companies' managers. A qualitative methodology based on the Qualitative Comparative Analysis (QCA) has therefore been applied for the cross-case analysis of companies in which ecoinnovation projects have been carried out. This methodology has been considered the most adequate due to the limited number of applied cases available.

Jenson et al (2015) stressed that Qualitative Comparative Analysis (QCA) (Rihoux et al, 2013) is consistent with the case-study tradition and provides for cross-case analysis of innovation with logical rigor (Berg-Schlosser et al, 2008). In this field, Ragin (2008) and Woodside (2010) applied fuzzy-set Qualitative Comparative Analysis (fsQCA) to high product-innovation performance (Cheng et al, 2013) and Coduras et al (2015) offer an novel application of fsQCA fuzzy-set qualitative comparative analysis to Global Entrepreneurship Monitor (GEM) data to demonstrate that it enriches previous conclusions from linear regression analyses. Beynon et al (2015) undertakes a crosscountry comparison of entrepreneurship attitudes using this methodology.

Although relevant to the current analysis, previous studies have not acknowledged in detail the measurement of the human capital available for the interrelated factor for ecoinnovation promoted through the corporate entrepreneurship: the human resources

\footnotetext{
${ }^{3} \mathrm{SABI}$ database contains comprehensive information on companies in Spain and Portugal. Further information at: http://www.bvdinfo.com/en-gb/our-products/company-information/national-products/sabi
} 
To cite this document: Sabina Scarpellini, Raquel Ortega-Lapiedra, Miguel Marco-Fondevila, Alfonso ArandaUsón, (2017). "Human capital in the eco-innovative firms: a case study of eco-innovation projects", International. Journal of Entrepreneurial Behavior \& Research, Vol. 23 Issue: 6, pp.919-933, https://doi.org/10.1108/ IJEBR-07-2017-0219 Permanent link to this document: https://doi.org/10.1108//JEBR-07-2017-0219

devoted to innovation, environmental issues and resources management. This human capital features the value creation of eco-innovation. First, eco-innovation typically involves dynamic processes that strongly depend on the firm's business strategy. Secondly, it needs a specific context where corporate entrepreneurship can flow. And finally, eco-innovation needs specific human resources, trained, specialized and able to work in a team.

Ketaka et al (2015) pointed out that the innovation outcome in companies can be summarized as resource/energy cost reduction and reduction of environmental stress. For this reason, in the present study, it has been considered that the human resources devoted to resources management are relevant. When top management team human capital is diverse in terms of education and experience, a wider range of cognitive frames are used to identify performance gaps and a broader spectrum of sources of new knowledge are considered (Weick, 1995). This enforces the importance of measuring different profiles of employees.

Burger et al (2013) reveal that the process of how know-how and capabilities are created by the team is more important than the mere existence of specific expertise. Many innovation and human capital studies measure regional and national level innovation activity, for example, the European Human Capital Index ${ }^{4}$ examines countries’ ability to develop and deploy their human capital by measuring training level and capabilities of the employees. McGuirk et al (2015) analyzed the small firms’ propensity to innovate and the willingness to increase the level of technology or computers involved in the employees work as well as the willingness to accept change in levels of skills necessary to carry out their job, and increased responsibility.

\footnotetext{
${ }^{4}$ Further information at: http://reports.weforum.org/human-capital-report-2015/press-releases/ (accessed on September of 2016).
} 
To cite this document: Sabina Scarpellini, Raquel Ortega-Lapiedra, Miguel Marco-Fondevila, Alfonso ArandaUsón, (2017). "Human capital in the eco-innovative firms: a case study of eco-innovation projects", International. Journal of Entrepreneurial Behavior \& Research, Vol. 23 Issue: 6, pp.919-933, https://doi.org/10.1108/ IJEBR-07-2017-0219 Permanent link to this document: https://doi.org/10.1108//JEBR-07-2017-0219

Overall, it seems to accept that individuals with higher value and higher specificity contribute more to innovation, although issues are still open such as what analysis system of human resource management is best suited to enhance the contribution of people innovation, depending on their type and operating manuals in line with the proposal of Lepak and Snell (2002). That is why the study variables are proposed to provide a more detailed picture of the human capital available for corporate entrepreneurship in companies with greater propensity for eco-innovation.

In general terms, previous studies have not acknowledged in detail the measurement of the human capital available for the interrelated factor for eco-innovation promoted through the corporate entrepreneurship: the human resources devoted to innovation, environmental issues and resources management. Thus, a specific constructed variable was defined in order to add new measurements to the variables previously applied by other authors.

A specific constructed variable was defined in order to add new measurements to the variables previously applied by other authors. This variable measures the presence of human capital devoted, directly or indirectly, to the three intrinsic factors of ecoinnovation: environment, innovation and resources management. The detailed variables listed on Table 2 are the data source for the analysis summarized in this paper and offer the methodological basis for the conceptualization of corporate entrepreneurship applied to eco-innovation and the determinant factors for its implementation. A series of variables inherent to the economic-financial characteristics of the firms were added to the descriptive project variables for the case analysis.

For each one of them, two options have been established (1: Yes and 0: No), so as to facilitate the comparative analysis. 
To cite this document: Sabina Scarpellini, Raquel Ortega-Lapiedra, Miguel Marco-Fondevila, Alfonso ArandaUsón, (2017). "Human capital in the eco-innovative firms: a case study of eco-innovation projects", International. Journal of Entrepreneurial Behavior \& Research, Vol. 23 Issue: 6, pp.919-933, https://doi.org/10.1108/ IJEBR-07-2017-0219 Permanent link to this document: https://doi.org/10.1108//JEBR-07-2017-0219

\begin{tabular}{|l|l|l|}
\hline CODE & Variable & Description of the variable \\
\hline X01 & STOCK & listed on a stock exchange \\
\hline X02 & AGE & Age of company: more than 10 years \\
\hline X03 & LRV & $\begin{array}{l}\text { Differences in capital structure, measured as liabilities to assets ratio : No dependent on } \\
\text { debt (0.49 or less); Dependent on debt (more than 0.5) }\end{array}$ \\
\hline X04 & LIAB ST & $\begin{array}{l}\text { Differences in debt structure, measured as short term liabilities to liabilities ratio : } \\
\text { dependent on long term debt (0.49 or less); Dependent on short term debt (more than 0.5) }\end{array}$ \\
\hline X05 & Green_Pat & $\begin{array}{l}\text { Ownership of patents related to environmental technologies, or green patents, measured } \\
\text { by a scale on which 1= has patents and 0= does not have patents }\end{array}$ \\
\hline X06 & ISOs & $\begin{array}{l}\text { Environmental/Energy management standards: EMAS or/and ISO 14001 or/and ISO } \\
\text { 50001 }\end{array}$ \\
\hline X07 & DES_HR & Human Resources specifically devoted to Product Design \\
\hline X08 & ENE_M & Presence of an Energy/Resources manager \\
\hline X09 & INN_M & Presence of an Innovation Manager \\
\hline X10 & ENVIN_M & Presence of an Waste/Environmental manager \\
\hline X11 & INT_ENT & $\begin{array}{l}\text { Presence of Internal promotion for Entrepreneurship innovation measured by a scale on } \\
\text { which 1= has internal promotion for entrepreneurship innovation and 0= does not have it }\end{array}$ \\
\hline X12 & RE & $\begin{array}{l}\text { Profitability above the sector average = 1; Below the sector average = 0 (studied for the } \\
\text { years 2010-2014) }\end{array}$ \\
\hline X13 & END & $\begin{array}{l}\text { Debt above the sector average = 1; Below the sector average = 0 (studied for the years } \\
\text { 2010-2014) }\end{array}$ \\
\hline X14 & MARKET & Dominant market share of the company = 1 above 10\%; Below 10\% = 0 \\
\hline
\end{tabular}

The study variables are grouped in four categories:

a. Company characteristics: X1; X2; X5; X6

b. Internal policies: X7; X11

c. Human resources managers: X8; X9; X10

d. Economic factors: X12; X13; X3; X4; X14

The presence of a specific department responsible for each one of the three areas

Environment; Innovation and Energy was introduced into the variables lists. In fact, cross-functional teams are considered an important antecedent of successful product innovation (Cooper \& Edgett, 2008).

From another perspective, Hayton (2005) proposes a three-dimensional framework for describing and measuring a firm’s Intellectual Capital that includes human capital, intellectual property, and reputational capital. Thus, variables concerning these three aspects were considered for the study. In addition, a variable regarding the corporate 
To cite this document: Sabina Scarpellini, Raquel Ortega-Lapiedra, Miguel Marco-Fondevila, Alfonso ArandaUsón, (2017). "Human capital in the eco-innovative firms: a case study of eco-innovation projects", International. Journal of Entrepreneurial Behavior \& Research, Vol. 23 Issue: 6, pp.919-933, https://doi.org/10.1108/ IJEBR-07-2017-0219 Permanent link to this document: https://doi.org/10.1108//JEBR-07-2017-0219

entrepreneurship of the analyzed companies in the framework of innovation and venturing (Zahra et al, 2000) was added to the list as well as the certified standards ISO14001, ISO50001 (Lim and Prakash, 2014) and EMAS due to the implication they have as voluntary scheme for the environmental management and the second-order effects on innovation, beyond the first-order effect on pollution and regulatory compliance (Lim and Prakash 2014).

\section{Findings}

The Qualitative Comparative Analysis (QCA) conducted with the eight cases sample brings in the main results in terms of necessary conditions (those which have to be present to make possible the eco-innovation practice), and sufficient conditions (those which permit to forecast the presence of eco-innovation practice).

In all eight cases (Y1-8) the conditions X2, X9, X10, X13, X3 and X4 are met, and so: all companies are more than 10 years old (necessary condition 1, nc1); count on managers for environment and innovation (nc 2); and show higher than the sector average levels of debt, with a strong tendency to external funds and short term (nc 3).

The conditions X1 and X12 appear to be irrelevant, since they both present positive and negative results for the companies analyzed, as well as in other cases which have not been characterized as 'intellectual capital entrepreneurs'. In synthesis, whether the company is listed or unlisted in stock exchange has no relevance to the present study as well as whether the company has or not a higher economic profitability than the sector average. Table 3 shows the results:

Table 3.- Principal results of the simplified QCA analysis

\begin{tabular}{|c|c|c|c|c||c|c||c|c|c||c|c|c|c|c|}
\hline $\mathbf{Y}$ & $\mathbf{X 1}$ & $\mathbf{X} 2$ & $\mathbf{X} 5$ & $\mathbf{X 6}$ & $\mathbf{X 7}$ & $\mathbf{X 1 1}$ & $\mathbf{X 8}$ & $\mathbf{X 9}$ & $\mathbf{X 1 0}$ & $\mathbf{X 1 2}$ & $\mathbf{X 1 3}$ & $\mathbf{X 3}$ & $\mathbf{X} 4$ & $\mathbf{X 1 4}$ \\
\hline Y1 & 0 & 1 & 1 & 1 & 1 & 1 & 1 & 1 & 1 & 0 & 1 & 1 & 1 & 1 \\
\hline Y2 & 0 & 1 & 0 & 0 & 1 & 0 & 1 & 1 & 1 & 0 & 1 & 1 & 1 & 0 \\
\hline
\end{tabular}


To cite this document: Sabina Scarpellini, Raquel Ortega-Lapiedra, Miguel Marco-Fondevila, Alfonso ArandaUsón, (2017). "Human capital in the eco-innovative firms: a case study of eco-innovation projects", International. Journal of Entrepreneurial Behavior \& Research, Vol. 23 Issue: 6, pp.919-933, https://doi.org/10.1108/ IJEBR-07-2017-0219 Permanent link to this document: https://doi.org/10.1108//JEBR-07-2017-0219

\begin{tabular}{|l|l|l|l|l||l|l||l|l|l||l|l|l|l|l|} 
Y3 & 0 & 1 & 0 & 0 & 1 & 0 & 0 & 1 & 1 & 0 & 1 & 1 & 1 & 0 \\
\hline Y4 & 0 & 1 & 0 & 1 & 1 & 0 & 1 & 1 & 1 & 0 & 1 & 1 & 1 & 0 \\
\hline Y5 & 0 & 1 & 0 & 1 & 0 & 1 & 1 & 1 & 1 & 0 & 1 & 1 & 1 & 0 \\
\hline Y6 & 1 & 1 & 1 & 1 & 1 & 0 & 1 & 1 & 1 & 0 & 1 & 1 & 1 & 1 \\
\hline Y7 & 0 & 1 & 0 & 1 & 0 & 1 & 1 & 1 & 1 & 0 & 1 & 1 & 1 & 1 \\
\hline Y8 & 0 & 1 & 1 & 1 & 1 & 1 & 1 & 1 & 1 & 1 & 1 & 1 & 1 & 1 \\
\hline
\end{tabular}

The remaining variables, which could be the sufficient conditions to explain the eight cases, show different and unclear patterns, leading to a specific study analyzing all possible combinations among the 5 variables, which results in 32 cases (Table 4).

Table 4. Specific combinations of sufficient variables in Table 3

$1 \quad 2 \quad 3 \quad 4 \quad 5 \quad 6 \quad 7 \quad 8 \quad 9 \quad 1011121314151617181920212223242526272829303132$

\begin{tabular}{|c|c|c|c|c|c|c|c|c|c|c|c|c|c|c|c|c|c|c|c|c|c|c|c|c|c|c|c|c|c|c|c|c|}
\hline X5 & 1 & 0 & 1 & 0 & 1 & 0 & 1 & 0 & 1 & 0 & 1 & 0 & 1 & 0 & 1 & 0 & 1 & 0 & 1 & 0 & 1 & 0 & 1 & 0 & 1 & 0 & 1 & 0 & 1 & 0 & & 0 \\
\hline X6 & 1 & 1 & 1 & 1 & 1 & 1 & 1 & 1 & 1 & 1 & 1 & 1 & 1 & 1 & 1 & 1 & 0 & 0 & 0 & 0 & 0 & 0 & 0 & 0 & 0 & 0 & 0 & 0 & 0 & 0 & 0 & 0 \\
\hline X7 & 1 & 1 & 0 & 0 & 1 & 1 & 1 & 1 & 0 & 0 & 1 & 1 & 0 & 0 & 0 & 0 & 1 & 1 & 0 & 0 & 0 & 0 & 1 & 1 & 1 & 1 & 0 & 0 & 1 & 1 & \begin{tabular}{l|l}
0 \\
\end{tabular} & 0 \\
\hline X11 & 1 & 1 & 1 & 1 & 0 & 0 & 1 & 1 & 0 & 0 & 0 & 0 & 1 & 1 & 0 & 0 & 0 & 0 & 1 & 1 & 0 & 0 & 1 & 1 & 0 & 0 & 1 & 1 & 1 & 1 & 0 & 0 \\
\hline X14 & 1 & 1 & 1 & 1 & 1 & 1 & 0 & 0 & 1 & 1 & 0 & 0 & 0 & 0 & 0 & 0 & 0 & 0 & 0 & 0 & 1 & 1 & 0 & 0 & 1 & 1 & 1 & 1 & 1 & 1 & 0 & 0 \\
\hline
\end{tabular}

The crossing of the results yields the following two possible solutions for the sufficient conditions explaining the 8 cases (Y1-8), as it is shown in Table 5:

Table 5.- Possible solutions for the selection of cases.

\begin{tabular}{|c||c|c||c|c||c||c|}
\hline Y\Xn & $\mathbf{X}$ 5 & $\mathbf{X 6}$ & $\mathbf{X 7}$ & $\mathbf{X 1 1}$ & $\mathbf{X 1 4}$ & \\
\hline Y1 & 1 & 1 & 1 & 1 & 1 & Case 1 \\
\hline Y2 & 1 & 0 & 1 & 0 & 0 & Case 17 \\
\hline Y3 & 0 & 0 & 1 & 0 & 0 & Case 18 \\
\hline Y4 & 0 & 1 & 1 & 0 & 0 & Case 12 \\
\hline Y5 & 1 & 1 & 0 & 1 & 0 & Case 13 \\
\hline Y6 & 0 & 1 & 1 & 0 & 1 & Case 6 \\
\hline Y7 & 0 & 1 & 0 & 1 & 1 & Case 4 \\
\hline Y8 & 1 & 1 & 1 & 1 & 1 & Case 1 \\
\hline
\end{tabular}

$$
\begin{gathered}
\text { Possible cases } \\
j=2(1,0) ; k=5(X n) \\
\pi(j)^{k}=2^{5}=32 \text { cases }
\end{gathered}
$$

As principal result of the analysis, the possible solutions are: 
To cite this document: Sabina Scarpellini, Raquel Ortega-Lapiedra, Miguel Marco-Fondevila, Alfonso ArandaUsón, (2017). "Human capital in the eco-innovative firms: a case study of eco-innovation projects", International. Journal of Entrepreneurial Behavior \& Research, Vol. 23 Issue: 6, pp.919-933, https://doi.org/10.1108/ IJEBR-07-2017-0219 Permanent link to this document: https://doi.org/10.1108//JEBR-07-2017-0219

Solution 1: The necessary conditions 1,2 and 3 are satisfied jointly with the sufficient condition of possessing a certified environmental management system (X6) or the sufficient condition of having human resources devoted to the product design (X7).

$$
\mathrm{S} 1: \mathrm{X} 2 * \mathrm{X}(9,10) * \mathrm{X}(13,3,4) *(\mathrm{X} 6+\mathrm{X} 7) \text {. }
$$

Solution 2: The necessary conditions 1,2 and 3 are satisfied jointly with the sufficient condition of having human resources devoted to the product design (X7) or the sufficient condition of promoting entrepreneurship in intellectual capital among employees (X11).

$$
\text { S2: } \mathrm{X} 2 * \mathrm{X}(9,10) * \mathrm{X}(13,3,4) *(\mathrm{X} 7+\mathrm{X} 11) \text {. }
$$

Combining both solutions in a single equation, the condition of having human resources devoted to product design (X7) becomes a necessary condition, while the possession of certified environmental management systems (X6) and the condition of promoting entrepreneurship in intellectual capital among employees (X11) become substitutable.

$$
\text { S: } X 2 * X(9,10) * X(13,3,4) * X 7 *(X 6+X 11)
$$

\section{Conclusions}

The full integration of environmental concerns within the internal capabilities and firm's own assets is far from being reached, even in advanced and competitive industrial regions. Nevertheless, the environmental concerns are strategically considered by firms far more than in the past. Consequently, the role of $\mathrm{HR}$ in the environmental performance improvement must be explored and organized for the development of eco-innovations. In this context, based on the information/decision-making perspective, the companies' specialized HR and the principal economic and finance variables have been analyzed 
To cite this document: Sabina Scarpellini, Raquel Ortega-Lapiedra, Miguel Marco-Fondevila, Alfonso ArandaUsón, (2017). "Human capital in the eco-innovative firms: a case study of eco-innovation projects", International. Journal of Entrepreneurial Behavior \& Research, Vol. 23 Issue: 6, pp.919-933, https://doi.org/10.1108/ IJEBR-07-2017-0219 Permanent link to this document: https://doi.org/10.1108//JEBR-07-2017-0219

through a qualitative comparative approach of 8 Spanish eco-innovative applied projects.

The main conclusion from the QCA analysis indicates that the role of the specialized HC involved in the R\&D and innovation activities, the environmental management of firms and the resources (energy) management, are relevant to the eco-innovative process and have to be specifically managed for the development of eco-innovations. The qualitative analysis shows that firms devoting specialized human capital to the eco-innovation activities are companies at least 10 years old, which have $R \& D$ and innovation departments, as well as a specific department for the environmental management, they have been certified through some environmental certification standards, they have human resources devoted to the product design, they promote entrepreneurship for innovation among their own employees and they also have higher than the sectoral average rates of leverage.

The results obtained through this paper contribute to the academic knowledge in the field of human capital management from an integrated approach through empirical evidences of resources and capabilities of the firms applied to the corporate entrepreneurship and eco-innovation. Furthermore, another relevant contribution of this study is defining the variables to be used when measuring the human capital that is available for eco-innovation in an eco-innovative firm.

The mains conclusions are of interest for practitioners in charge of the eco-innovation development in firms, since they help defining the optimum level of resources to be applied to the eco-innovation projects and to strategically manage the human capital for the corporate entrepreneurship. As a novel application for the decision making process, the influence of human capital (HC) in terms of eco-innovative entrepreneurship has been analyzed to define the level and competences of human capital specifically devoted to eco-innovation, thus supporting policy makers when designing long term 
To cite this document: Sabina Scarpellini, Raquel Ortega-Lapiedra, Miguel Marco-Fondevila, Alfonso ArandaUsón, (2017). "Human capital in the eco-innovative firms: a case study of eco-innovation projects", International. Journal of Entrepreneurial Behavior \& Research, Vol. 23 Issue: 6, pp.919-933, https://doi.org/10.1108/ IJEBR-07-2017-0219 Permanent link to this document: https://doi.org/10.1108//JEBR-07-2017-0219

policies and initiatives aiming at increasing competitiveness and added value of business.

The main limitations of this paper are related to the number of analyzed study cases. Nevertheless, given that the empirical research addressing the interrelated factors of ecoinnovation and human capital are still not numerous, this study provides an interesting starting point for discussion and to the improvement of the qualitative method applied. Moreover, further research is still needed to fully elucidate how the corporate entrepreneurship is promoted to respond to the eco-innovation strategy of firms, as well as to deeply explore the characteristics of the intellectual capital concerned to the ecoinnovation processes.

\section{Acknowledgments}

This study was partially funded by the Spanish Ministry of Economy and Competitiveness, Project ECO2013-45599-R. The eco-innovation campaign described in this paper was co-financed by the Regional Government of Aragón (Spain) and the Spanish Ministry of Economy and Competitiveness, within the framework of the Project called "Plan de Fomento de la Eco-innovación Empresarial en Aragón” carried out by CIRCE - Research Centre for Energy Resources and Consumption - www.fcirce.es. The collaboration of all participating companies is particularly acknowledged and the contributions of Prof. Antonio Valero, Scientific Director of the project, and Eng. Miguel Ángel García Muro are gratefully acknowledged.

\section{References}

Albers, J.A. and Brewer, S. (2003). "Knowledge Management and The Innovation Process: The Eco-Innovation Model”. Journal of Knowledge Management Practice, Vol. 10, No. 1, pp. 1-8 
Andersen, M. (2002). “'Organising interfirm learning: as the market begins to turn green’', in de Bruijn, T.J.N.M. and Tukker, A. (Eds), Partnership and Leadership: Building Alliances for a Sustainable Future, Kluwer, Dordrecht, Vol. 8 No 1, pp. 103-119.

Antoncic, B. and Hisrich, R.D. (2001). "Intrapreneurship: construct refinement and crosscultural validation”. Journal of Business Venturing Vol.16 No. 5, pp. 495-527.

Antonioli, D., Mancinelli, S. and Mazzanti, M. (2013). "Is environmental innovation embedded within high-performance organisational changes? The role of human resource management and complementarity in green business strategies”. Research Policy, Vol. 42 No 4, pp. 975-988.

Aragon-Correa, JA. (1998). "Strategic proactivity and firm approach to the natural environment”. Academy of Management Journal. Vol. 41 No. 5, pp. 556-567.

Aragon-Correa, J.A. and Sharma S. (2003). “A contingent resource-based view of proactive corporate environmental strategy”. Academy of Management Review Vol. 28 No.1, pp. 71-88.

Arrow, K. (1962). "The economic implications of learning by doing”. Review of Economic Studies. Vol. 29 No. 2, pp. 155-173.

Barney, J. B., Ketchen, D. J., and Wright, M. (2011). “The future of resource-based theory: revitalization or decline?” Journal of Management, Vol. 37 No. 5., pp. 1299-1315.

Bennett, S.J. (1991). Ecopreneuring: the Complete Guide to Small Business Opportunities from the Environmental Revolution. Wiley. New York.

Berg-Schlosser, D., De Meur, G., Rihoux, B., and Ragin, C. (2009). “Qualitative comparative analysis (QCA) as an approach”. In B. Rihoux, \& C. C. Ragin (Eds.) Configurational comparative methods: Qualitative comparative analysis (QCA) and related techniques, pp. 1-18, Sage. Los Angeles.

Berrone, P., Fosfuri, A., Gelabert, L. and Gomez-Mejia, L.R. (2013), "Necessity as the mother of 'green' inventions: Institutional pressures and environmental innovations”. Strategic Management Journal, Vol. 34 No. 8, pp. 891-909.

Beynon, M.J., Jones, P. and Pickernell, D. (2015), "Country-based comparison analysis using fsQCA investigating entrepreneurial attitudes and activity”. Journal of Business Research, Vol. 69 No. 4, pp. 1271-1276

Birkinshaw, J. (1997), "Entrepreneurship in multinational corporations. The characteristics of subsidiary initiatives”. Strategic Management Journal, Vol.18 No. 3, pp. 207-229.

Brunnermeier, S.B. and Cohen M.A.. (2003), "Determinants of environmental innovation in U.S. manufacturing industries”. Journal of Environmental Economics and Management, Vol. 45 No 2, pp. 278-293.

Burger, N. Staake, T., Fleisch, E., Hierold, C. (2013), "Managing technology development teams - exploring the case of microsytems and nanosystems”. R\&D Management, Vol. 43 No 2, pp. 162-186.

Bugelman. (1983). "Corporate Entrepreneurship and strategic management: insights from a process study”. Management Science, Vol. 29 No. 12, pp. 1349-1364.

Carrillo-Hermosilla, J., del Río, P. and Könnölä, T. (2010), "Diversity of eco-innovations: Reflections from selected case studies”. Journal of Cleaner Production, Vol.18 No. 10/12, pp. 1073-1083.

Cheng, C.F., Chang, M.L. and Li, C.S. (2013), "Configural paths to successful product innovation”. Journal of Business Research, Vol. 66 No. 12, pp. 2561-2573.

Cohen B. (2006), "Sustainable valley entrepreneurial ecosystems". Business Strategy and the Environment, Vol.15 No. 1, pp. 1-14. 
To cite this document: Sabina Scarpellini, Raquel Ortega-Lapiedra, Miguel Marco-Fondevila, Alfonso ArandaUsón, (2017). "Human capital in the eco-innovative firms: a case study of eco-innovation projects", International. Journal of Entrepreneurial Behavior \& Research, Vol. 23 Issue: 6, pp.919-933, https://doi.org/10.1108/ IJEBR-07-2017-0219 Permanent link to this document: https://doi.org/10.1108//JEBR-07-2017-0219

Coduras, A., Guerrero, M. and Peña, I. (2011). Emprendimiento Corporativo en España. GEM España-Fundación Xavier de Salas para la Dirección General de Política de la Pyme. Madrid. Spain

Coduras, A., Clemente, J.A. and Ruiz, J. (2016). “A novel application of fuzzy-set qualitative comparative analysis to GEM data”. Journal of Business Research Vol. 69 No. 4, pp. $1265-1270$

Cooper, R.G. and Edgett, S.J. (2008), “Maximizing productivity in product innovation”. Research Technology Management, Vol. 51 No. 2, pp. 47-58.

Covin, J.G. and Miles, M.P. (1999), "Corporate entrepreneurship and the pursuit of competitive advantage”. Entrepreneurship, Theory and Practice Vol. 23 No. 3, pp. 47-63.

Delgado-Verde, M., Amores-Salvadó, J., Martín-de Castro, G. and Navas-López, J.E. (2015). "Green intellectual capital and environmental product innovation: the mediating role of green social capital”. Knowledge Management Research \& Practice, Vol. 12 No. 3, pp. 261-275.

Dess, G.G., Ireland, R.D., Zahra, S.A, Flody, S.W., Janney, J.J and Lane, P.J. (2003). "Emerging Issues in Corporate Entrepreneurship". Journal of Management, Vol. 29 No. 3, pp. 351-378.

Finkle, T.A. (2012). "Corporate Entrepreneurship and Innovation in Silicon Valley: The Case of Google, Inc.”. Entrepreneurship Theory and Practice. Vol 36 No. 4, pp. 863-884.

Fitjar, R., Rodriguez-Pose, A. (2011). "Innovating in the periphery: firms, values and innovation in Southwest Norway”. European Planning Studies Vol. 19 No. 4, pp. 555574.

Florida R, Davison D. (2001). “Gaining from green management: environmental management systems inside and outside the factory”. California Management Review, Vol. 43 No. 3, pp. 64-84.

Foxon, T. and Pearson P. (2008). "Overcoming barriers to innovation and diffusion of cleaner technologies: some features of a sustainable innovation policy regime". Journal of Cleaner Production, Vol. 16 No. 1, pp. 148-169.

Ganotakis, P. (2012). "Founders' human capital and the performance of UK new technology based firms”. Small Business Economics, Vol. 39, No. 2, pp. 495-515.

Gimmon, E. and Levie, J. (2010). "Founder's human capital, external investment, and the survival of new high-technology ventures”. Research Policy Vol. 39 No. 9, pp. 12141226.

Grant, R.M. (1996). ”Toward a Knowledge-Based Theory of the Firm”. Strategic Management Journal, Vol. 17 No. 2, pp. 109-122.

Guth, W. and Ginsberg, A. (1990). “Guest editors' introduction: Corporate entrepreneurship”. Strategic Management Journal, Vol. 11 No. 4, pp. 297-308.

Hansen, E.G., Grosse-Dunker, F. and Reichwald, R. (2009). "Sustainability innovation cube: a framework to evaluate sustainability-oriented innovations”. International Journal of Innovation Management, Vol. 13 No. 4, pp. 683-713.

Hayton, J.C. (2005). "Competing in the new economy: the effect of intellectual capital on corporate entrepreneurship in high-technology new ventures”. R\&D Management, Vol. 35 No. 2, pp. 137-155.

Hill, C.W.L. and Rothaermel, F. (2003). "The performance of incumbent firms in the face of radical technological innovation”. Academy of Management Review, Vol. 28 No 2, pp. 257-274.

Hitt, M.A., Bierman, L., Shimizu, K. and Kochhar, R. (2001). "Direct and moderating effects of human capital on strategy and performance in professional service firms: a resourcebased perspective”. Academy of Management Journal, Vol. 44 No. 1, pp. 13-28. 
Hoffman A.J. (1999). "Institutional evolution and change: environmentalism and the U.S. chemical industry”. Academy of Management Journal, Vol. 42 No. 4, pp. 351-371.

Hong Chung, L. and Gibbons, P.T. (1997). “Corporate Entrepreneurship The Roles of Ideology and Social Capital”. Group Organization Management, Vol. 22 No. 1 pp. 10-30.

Holt, D. (2012). “The Journey of a 'Green’ Micro-Enterprise - The Green Planet”. Corporate Social Responsibility and Environmental Management, Vol. 19, No. 2, pp. 90-101.

Horbach, J., Rammerb, C., and Rennings, K. (2012). “Determinants of eco-innovations by type of environmental impact — The role of regulatory push/pull, technology push and market pull”. Ecological Economics, Vol. 78 No. 1, pp. 112-122.

Huarng, K.H. and Yu, T.H.K. (2011). "Entrepreneurship, process innovation and value creation by a nonprofit SME”. Management Decision, Vol. 49 No. 2, pp. 284-296.

Hurt, H. T., Joseph, K., and Cook, C.D. (1977). 'Scales for the measurement of innovativeness'. Human Communication Research, Vol. 4 No. 1, pp. 58-65.

Jenson, I., Leith, P., Doyle, R., West, J. and Miles, M.P. (2015). “Testing innovation systems theory using Qualitative Comparative Analysis”. Journal of Business Research, Vol. 69 No. 4, pp. 1283-1287.

Jimenez-Jimenez, D., and Sanz-Valle, R. (2011). "Innovation, organizational learning, and performance”. Journal of Business Research, Vol. 64 No. 4, pp. 408-417.

Kelley D.J., Peters, L. Colarelli O'Connor, G. (2009). “Intra-organizational networking for innovation-based corporate entrepreneurship". Journal of Business Venturing, Vol. 24 No. 3, pp. 221-235.

Kemp, R. and Pearson, P. (2007). “Final report MEI project about measuring ecoinnovation”. MEI Project Report. http://www.oecd.org/env/consumption-innovation/43960830.pdf. (Accessed on March 2017)

Ketata, I., Sofka, W., Grimpe, C. (2015). “The role of internal capabilities and firms' environment for sustainable innovation: evidence for Germany”. R\&D Management, Vol 45 No. 1, pp. 60-75.

Kirkwood, J., Walton, S. (2010). "What motivates ecopreneurs to start businesses?" International Journal of Entrepreneurial Behavior \& Research, Vol. 16 No. 3, pp. 204228.

Kuratko, D.F. (2007). “Corporate Entrepreneurship”. Foundations and Trends in Entrepreneurship, Vol. 3 No. 2, pp. 1-51.

Lepak, D.P. and Snell, S.A. (2002). "Examining the human resource architecture: The relationships among human capital, employment, and human resource configurations". Journal of Management, Vol. 28 No. 4, pp. 517-543.

Llera-Sastresa, E., Marco-Fondevila, M., Scarpellini, S., Aranda, J. and Aranda-Usón, A. (2013). Nichos de empleo sostenible y emprendizaje innovador. CESA - Consejo Económico y Social de Aragón. pp. 162-172 [in Spanish]. Zaragoza Spain.

Lim, S. and Prakash, A. (2014). "Voluntary Regulations and Innovation: The Case of ISO 14001”. Public Administration Review, Vol. 74, No. 2, pp. 233-244.

Lober, D.J. (1998). "Pollution prevention and corporate entrepreneurship". Journal of Organizational Change Management, Vol.11 No. 1, pp. 26-37.

De Marchi V., Di Maria E. and Micelli, S. (2012). "Environmental strategies, upgrading and competitive advantage in global value chains”. Business Strategy and the Environment, Vol. 22 No. 1, pp. 62-72.

Scott Marshall, R., Cordano, M. and Silverman, M. (2005). "Exploring Individual and Institutional Drivers of Proactive Environmentalism in the US Wine Industry”. Business Strategy and the Environment, Vol.14 No. 2, pp. 92-109 
To cite this document: Sabina Scarpellini, Raquel Ortega-Lapiedra, Miguel Marco-Fondevila, Alfonso ArandaUsón, (2017). "Human capital in the eco-innovative firms: a case study of eco-innovation projects", International. Journal of Entrepreneurial Behavior \& Research, Vol. 23 Issue: 6, pp.919-933, https://doi.org/10.1108/ IJEBR-07-2017-0219 Permanent link to this document: https://doi.org/10.1108//JEBR-07-2017-0219

Martin, L., McNeill, T., and Warren-Smith, I. (2013) "Exploring business growth and eco innovation in rural small firms", International Journal of Entrepreneurial Behavior \& Research, Vol. 19 No. 6, pp.592-610.

McGuirk, H. and Jordan, D. (2012). ”Local labour market Diversity and Business Innovation: Evidence from Irish manufacturing Businesses”. European Planning Studies, Vol. 20 No. 12, pp. 1945-1960.

McGuirk, H., Lenihan, H. and Hartc, M. (2015). "Measuring the impact of innovative human capital on small firms’ propensity to innovate”. Research Policy, Vol. 44 No. 4, pp. 965976.

Mercier-Laurent, E. (2011). From Innovation to Eco-innovation, Innovation Ecosystems, John Wiley \& Sons, Inc, Hoboken, NJ, USA.

Morris, M.H, and Kuratko, D.F. (2002). Corporate Entrepreneurship, Dallas, TX, USA, Harcourt Press.

Nelson, R. and Winter, S. (1982). An Evolutionary Theory of Economic Change. Cambridge, MA: Harvard University Press.

Nicolopoulou, K. (2014). "Social Entrepreneurship between Cross-Currents: Toward a Framework for Theoretical Restructuring of the Field". Journal of Small Business Management, Vol. 52 No. 4, pp. 678-702.

OECD, Eurostat. (2005). Oslo Manual: Guidelines for Collecting and Interpreting Innovation Data ( $3^{\mathrm{a}}$ ed.). OECD publishing. Paris.

OECD (2009). Eco-Innovation in Industry Enabling Green Growth. Ed. OECD Organization for Economic Co-operation and Development. Paris.

OECD, (2011). “Skills for Innovation and Research”. OECD Publishing. Available at: http://www.oecd-ilibrary.org/science-andtechnology/skills-for-innovation-and-research 9789264097490-en (accessed on November 2015).

Pastakia, A. (1998). “Grassroots ecopreneurs: change agents for a sustainable society”. Journal of Organizational Change Management, Vol.11 No. 2, pp. 157-173.

Parker, S. (2011). “Intrapreneurship or entrepreneurship?”. Journal of Business Venturing, Vol. 26 No. 1, pp. 19-34.

Phan, P., Wright, M., Ucbasaran, D. and Tan, W. (2009). "Corporate Entrepreneurship: Current research and future directions”. Journal of Business Venturing, Vol.24, No. 3, pp. 197205.

Pizarro Moreno, I., Real., Real, J.C., and De la Rosa., M.D. (2011). "La incidencia del capital humano y la cultura emprendedora en la innovación” Cuadernos de Economía y Dirección de la Empresa, Vol. 14, No. 3, pp. 139-150 [In Spanish] Asociación Científica de Economía y Dirección de Empresas . Madrid, España

Porter, M.E. (1990). The Competitive Advantage of Nations. Free Press. New York.

Porter, M.E. and Van der Linde, C. (1995). "Toward a new conception of the environmentcompetitiveness relationship”. Journal of Economic Perspectives, Vol. 9 No. 4 pp. 97118.

Prakash, A. (2001). “Why do firms adopt 'beyond-compliance' environmental policies?” Business Strategy and the Environment, Vol. 10 No. 5, pp. 286-299.

Ramus, C.A. and Steger, U. (2000). "Managerial interpretations and organizational context as predictors of corporate choice of environmental strategy". Academy of Management Journal, Vol. 43 No. 4, pp. 605-626.

Ragin, C.C. (2008). Redesigning social inquiry: Fuzzy sets and beyond. University of Chicago Press. Chicago.

Rennings, K. (2000). "Redefining innovation: eco-innovation research and contribution from ecological economics”. Ecological Economics Vol. 32 No. 2, pp. 319-332. 
Ribeiro, D. and Huarng, K.H. (2013). “Innovation and entrepreneurship in knowledge industries”. Journal of Business Research, Vol. 64 No. 11, pp. 1224-1228.

Rihoux, B., Álamos-Concha, P., Bol, D., Marx, A. and Rezsöhazy, I. (2013). "From niche to mainstream method? A comparative mapping of QCA applications in journal articles from 1984 to 2011”. Political Research Quarterly, Vol. 66 No. 1, pp. 175-184.

Robson, P.J.A., Akuetteh, C.K., Westhead, P. and Wright, M., (2012). “Innovative opportunity pursuit, human capital and business ownership experience in an emerging region: evidence from Ghana”. Small Business Economics Vol.39 No. 3, pp. 603-625.

Rossi, C., Cricelli, L., Grimaldi, M. and Greco, M. (2016). "The strategic assessment of intellectual capital assets: An application within Terradue Srl.”, Journal of Business Research. Vol.69 No. 5, pp. 1598-1603.

Rule, E., and Irwin, D. (1988). "Fostering intrapreneurship: The new competitive edge”. Journal of Business Strategy, Vol. 9 No. 3, pp. 44-47.

Scarpellini, S., Llera, E., Aranda, J., Marco Fondevila, M. and Aranda-Usón, A. (2012). R\&D and Eco innovation: Opportunities for Closer Collaboration between University and Companies through Technology Centres. Clean Technology and Environmental Policy Vol. 14 No. 6, pp. 1047-1058.

Scarpellini, S., Valero-Gil, J. and Portillo-Tarragona, P. (2016). "The "economic-finance interface” for eco-innovation projects”. International Journal of Project Management Vol. 34 No 6, pp. 1012-1025.

Schaltegger S. (2002). “A framework for ecopreneurship. Leading bioneers and environmental managers to ecopreneurship”. Greener Management International Vol. 1 No. 38, pp. 4558.

Schaltegger, S. and Wagner, M. (2010). "Sustainable entrepreneurship and sustainability innovation: categories and interactions”. Business Strategy and the Environment. Vol. 20 No. 4, pp. 222-237.

Sharma, S., Pablo, A.L. and Vredenburg, H. (1999). "Corporate Environmental Responsiveness Strategies. The importance of Issue Interpretation and Organizational Context”. Journal of Applied Behavioural Science, Vol. 35 No. 1, pp. 87-108.

Sharma, S. (2000). "Managerial interpretations and organizational context as predictors of corporate choice of environmental strategy". Academy of Management Journal Vol.43 No. 4, pp. 681-697.

Schultz, T.W., (1961). "Investment in human capital”. American Economic Review Vol. 51 No. 1, pp. 1-17.

Schumpeter, J. (1934). The Theory of Economic Development, New Brunswick: Transaction Publishers. London

Scott, J.M., and Thompson, J. (2012) "Making Ecopreneurs: Developing Sustainable Entrepreneurship (2nd ed.)", International Journal of Entrepreneurial Behavior \& Research, Vol. 18 No. 3, pp. 383-386.

Seebode, D., Jeanrenaud, S and Bessant, J. (2012). “Managing innovation for sustainability”. $R \& D$ Management. Vol. 42 No. 3, pp. 195-206.

Siltaoja, M.E. (2014). "Revising the Corporate Social Performance Model - Towards Knowledge Creation for Sustainable Development”. Business Strategy and the Environment. Vol. 23 No. 5, pp. 289-302.

Sing Wong, S.K. (2013). "Environmental Requirements, Knowledge Sharing and Green Innovation: Empirical Evidence from the Electronics Industry in China”. Business Strategy and the Environment. Vol. 22, No. 5, pp. 321-338.

Storper, M. and Scott, A.J. (2009). "Rethinking human capital, creativity and urban growth”. Journal of Economic Geography Vol. 9 No. 2, pp. 147-167. 
To cite this document: Sabina Scarpellini, Raquel Ortega-Lapiedra, Miguel Marco-Fondevila, Alfonso ArandaUsón, (2017). "Human capital in the eco-innovative firms: a case study of eco-innovation projects", International. Journal of Entrepreneurial Behavior \& Research, Vol. 23 Issue: 6, pp.919-933, https://doi.org/10.1108/ IJEBR-07-2017-0219 Permanent link to this document: https://doi.org/10.1108//JEBR-07-2017-0219

Susbauer, J, (1973). “Intracorporate Entrepreneurship: Programs in American Industry”. Cleveland: Cleveland State University.

Van der Borgh, M., Cloodt, M. and Romme A.G.L. (2012). "Value creation by knowledgebased ecosystems: evidence from a field study”. R\&D Management. Vol. 42 No. 2, pp. 150-169.

Von Krogh, G. and Geilinger, N. (2014). "Knowledge creation in the eco-system: Research imperatives”. European Management Journal, Vol. 32 No. 1, pp. 155-163.

Weick, K.E. (1995). Sensemaking in Organizations. Thousand Oaks. Sage. London

Woodside, A.G. (2010). "Bridging the chasm between survey and case study research: Research methods for achieving generalization, accuracy, and complexity”. Industrial Marketing Management, Vol. 39 No. 1, pp. 64-75.

Wu, C.W., Huarng, K.H. (2015). "Global entrepreneurship and innovation in management”. Journal of Business Research, Vol. 68 No. 4, pp. 743-747.

Yiu, D.W. and Lau, C.M. (2008). “Corporate Entrepreneurship as Resource Capital Configuration in Emerging Market Firms”. Entrepreneurship Theory and Practice. Vol. 32 No. 1, pp. 37-57.

Zahra, S.A., Neubaum, D.O. and Huse, M. (2000). "Entrepreneurship in medium-size companies: Exploring the effects of ownership and governance systems". Journal of Management, Vol. 26 No. 5, pp. 947-976.

Zhou, K.Z. and Li, C.B. (2012). "How knowledge affects radical innovation: knowledge base, market knowledge acquisition, and internal knowledge sharing”. Strategic Management Journal. Vol. 33 No. 9, pp. 1090-1102.

Zhu S, Chen R, Wu Y, Chen Q, Zhang X, Yu Z. (2009). “A mini-review on greenness of ionic liquids”. Chemical and Biochemical Engineering Quarterly Vol. 23 No. 2, pp. 207-211. 